\title{
Effect of increasing the protein-to-fat ratio and reducing fat content on the chemical and physical properties of processed cheese product
}

\author{
T. P. Guinee ${ }^{1}$ and D. J. O'Callaghan \\ Teagasc Food Research Centre Moorepark, Fermoy, Co. Cork, Ireland
}

\begin{abstract}
Scientific studies indicate that the intake of dietary fat and saturated fats in the modern Western diet is excessive and contributes adversely to health, lifestyle, and longevity. In response, manufacturers of cheese and processed cheese products (PCP) are pursuing the development of products with reduced fat contents. The present study investigated the effect of altering the fat level $(13.8,18.2,22.7,27.9$, and $32.5 \mathrm{~g} / 100 \mathrm{~g}$ ) in PCP on their chemical and physical properties. The PCP were formulated in triplicate to different fat levels using Cheddar cheese, skim milk cheese, anhydrous milk fat, emulsifying salt (ES), $\mathrm{NaCl}$, and water. The formulations were designed to give fixed moisture $(\sim 53 \mathrm{~g} / 100$ g) and ES:protein ratio (0.105). The resultant PCP, and their water-soluble extracts (WSE), prepared from a macerated blend of PCP and water at a weight ratio of $1: 2$, were analyzed at $4 \mathrm{~d}$. Reducing the fat content significantly increased the firmness of the unheated PCP and reduced the flowability and maximum loss tangent (fluidity) of the melted PCP. These changes coincided with increases in the levels of total protein, water-soluble protein, water-insoluble protein, and water-soluble $\mathrm{Ca}$, and a decrease in the molar ratio of water-soluble $\mathrm{Ca}$ to soluble P. However, both watersoluble $\mathrm{Ca}$ and water-soluble protein decreased when expressed as percentages of total protein and total $\mathrm{Ca}$, respectively, in the PCP. The high level of protein was a major factor contributing to the deterioration in physical properties as the fat content of PCP was reduced. Diluting the protein content or reducing the potential of the protein to aggregate, and thereby form structures that contribute to rigidity, may provide a means for improving quality of reduced-fat PCP by using natural cheese with lower intact casein content and lower calcium:casein ratio, for example, or by decreasing the ratio of sodium phosphate to sodium citrate-based ES.
\end{abstract} Key words: processed cheese, fat, rheology

Received February 11, 2013.

Accepted June 29, 2013.

${ }^{1}$ Corresponding author: tim.guinee@teagasc.ie

\section{INTRODUCTION}

Processed cheese products (PCP) are widely consumed as retail products (as spreads or slices) or as an ingredient in cheese-based dishes, including sandwiches, hamburgers, pizza, and lasagne. Their popularity as products may be attributed to several factors including, inter alia, the diversity they offer in flavor, texture, and cooking properties; easy customization to cheese ingredient applications; adaptability to fast food trade; and their attractive packaging into convenient formats and shapes. Such diversity is controlled by changes in formulation, processing conditions, and composition.

It is generally accepted that the intakes of dietary fat, saturated fats, and sodium in the modern Western diet are excessive and impair health, lifestyle, and longevity (Campbell et al., 1998; Simopoulos, 2002; Carrera-Bastos et al., 2011). Consequently, manufacturers of cheese and PCP, in an attempt to acquire greater market share, are pursuing the development of products with lower fat content. However, reduced-fat PCP are generally perceived as being tougher, harder, less creamy and spreadable, grainier, and more bitter than their full-fat equivalents (Muir et al., 1997). Consequently, much recent research in the area of PCP has focused on improvement of quality of reduced-fat products. Various parameters have been investigated, including addition of hydrocolloids (Brummel and Lee, 1990; Swenson et al., 2000), addition of lecithin (Drake et al., 1999), addition of various milk ingredients such as buttermilk (Raval and Mistry, 1999) and whey protein concentrates (Lee et al., 2006; Shenana et al., 2007), natural cheese characteristics (e.g., degree of maturity: Raval and Mistry, 1999; cheese made with or without exopolysaccharide-producing cultures: Hassan et al., 2007; pH and calcium content: Brickley et al., 2008), type and level of emulsifying salts (ES; Swenson et al., 2000; Raval and Mistry, 1999; Brickley et al., 2008), and product pH (Lee and Klostermeyer, 2001). These studies have indicated varying degrees of product improvement, depending on fat content, composition, and the product attribute(s) being assessed. In contrast, surprisingly few studies have considered the incremental effects of fat reduction on PCP. Solowiej (2012) 
reported that the hardness of cheese analogs, formed by blending acid casein dispersions and anhydrous milk fat (AMF), decreased as the protein content of the casein dispersion was increased from 12 to $20 \%$ and the level of AMF reduced from 30 to $10 \mathrm{~g} / 100 \mathrm{~g}$, despite an estimated increase in moisture content from approximately 62 to $74 \mathrm{~g} / 100 \mathrm{~g}$. Similarly, in other studies where data for control-fat and reduced-fat PCP are available (Brummel and Lee, 1990; Drake et al., 1999), it is difficult to infer the effects of fat reduction because of the confounding effect of moisture differences, which can sometimes be quite large (e.g., 10 to $20 \mathrm{~g} / 100 \mathrm{~g}$ ) between the treatments.

The objective of the current study was to investigate the effects of altering the fat content from approximately 33 to $14 \mathrm{~g} / 100 \mathrm{~g}$ on the physical properties of a PCP in which the moisture content was held constant and the protein-to-fat ratio was varied.

\section{MATERIALS AND METHODS}

\section{Raw Materials}

Cheddar cheese and skim milk cheese were manufactured as described below. The following ingredients were used: disodium phosphate anhydrous (DSP; Albright and Wilson Ltd., Cheshire, UK), trisodium citrate dihydrate (TSC; Jungbunzlauer GmbH, Pernhofen, Austria), sodium chloride (Irish International Trading Corp. PLC, Cork, Ireland), potassium sorbate (Sigma-Aldrich Chemie GmbH, Buchs, Switzerland), and butteroil (Corman Miloko Ireland Ltd., Carrick on Suir, Co. Tipperary, Ireland).

\section{Manufacture of Cheddar Cheeses of Varying Calcium Levels}

Cheddar cheese and skim milk cheese were manufactured on site at the Moorepark Technology Ltd. pilot plant using a standardized Cheddar cheesemaking procedure (Guinee and O'Kennedy, 2012). The cheese milks were standardized to protein and fat contents (g/100 g), respectively, of 3.33 and 3.27 for Cheddar and 3.34 and 0.16 for skim milk cheese. The cheeses were stored at $8^{\circ} \mathrm{C}$ and monitored periodically for level of primary proteolysis using levels of water-soluble $\mathrm{N}$ (WSN) and $\mathrm{pH}$ 4.6-soluble $\mathrm{N}$ (pH4.6SN). When the level of pH4.6SN (as g/100 g of total N) of individual cheeses reached $\sim 9.05(\sim 37 \mathrm{~d}$ for Cheddar, and $90 \mathrm{~d}$ for skim cheese), they were cut into cubes $\left(\sim 64 \mathrm{~cm}^{3}\right)$, frozen at $-18^{\circ} \mathrm{C}$, and stored until required. The cheeses were thawed at 4 to $8^{\circ} \mathrm{C}$ for $2 \mathrm{~d}$ before processing. Their compositions are given in Table 1.
Table 1. Composition of Cheddar and skim milk cheeses used in the manufacture of pasteurized processed cheese

\begin{tabular}{lcc}
\hline Cheese composition & Cheddar & $\begin{array}{c}\text { Skim milk } \\
\text { cheese }\end{array}$ \\
\hline Moisture $(\mathrm{g} / 100 \mathrm{~g})$ & 37.1 & 50.6 \\
Fat $(\mathrm{g} / 100 \mathrm{~g})$ & 33.9 & 0.7 \\
Protein $(\mathrm{g} / 100 \mathrm{~g})$ & 23.2 & 39.4 \\
Salt $(\mathrm{g} / 100 \mathrm{~g})$ & 1.7 & 1.8 \\
$\mathrm{pH}$ & 5.08 & 5.48 \\
Calcium $(\mathrm{mg} / 100 \mathrm{~g})$ & 675 & 1,229 \\
Calcium $(\mathrm{mg} / \mathrm{g}$ of protein) & 28.6 & 31.2 \\
Phosphorous $(\mathrm{mg} / 100 \mathrm{~g})$ & 511 & 837 \\
Phosphorous $(\mathrm{mg} / \mathrm{g}$ of protein) & 22.1 & 21.3 \\
WSN $\left(\%\right.$ of total N) $^{1}$ & 7.9 & 9.2 \\
pH4.6SN ${ }^{1}$ (\% of total N) & 7.5 & 8.7 \\
\hline
\end{tabular}

${ }^{1} \mathrm{WSN}=$ water-soluble $\mathrm{N} ; \mathrm{pH} 4.6 \mathrm{SN}=\mathrm{pH} 4.6$-soluble $\mathrm{N}$.

\section{Formulation Design and Manufacture of PCP}

A range of 5 formulations was designed with target fat levels in the range of 13.8 to $32.5 \mathrm{~g} / 100 \mathrm{~g}$ and proteinto-fat ratios varying from $\sim 0.38$ to $\sim 1.84$ using cheese, butteroil, water, and ES as ingredients in all treatments (Table 2). The target DM content was fixed at $54 \mathrm{~g} / 100$ $\mathrm{g}$, whereas the fat content was varied by altering the protein-to-fat ratio of the DM portion (Figure 1). The weight ratio of ES to cheese protein was kept constant at 0.105 to avoid the confounding effects of potential variations in protein hydration and physical properties associated with altering the level of ES (Shirashoji et al., 2006, 2010; Guinee and O'Kennedy, 2012). Similarly, the level of pH4.6SN (and hence intact casein content) in the natural cheese was kept in a narrow range ( $\sim 7.5$ to $8.5 \%$ of total $\mathrm{N}$; Table 1$)$ to minimize its potential effects (Garimella Purna et al., 2006; Brickley et al., 2007). To minimize the level of noncheese ingredients, skim cheese was used as the sole protein source in formulations with the 2 lowest fat levels, Cheddar cheese for the 2 highest fat levels, and a blend of skim and Cheddar cheese for the intermediate fat level. Butteroil was used with cheese to attain the desired fat levels. The formulation recipes were generated as a mixture design with target levels for fat, moisture, and ES:casein ratio using least squares optimization by means of the Excel Solver tool (Microsoft Excel 2003; Microsoft Corp., Redmond, WA). Ingredient quantities were based on analysis of all ingredients for moisture, fat, protein, ash, and lactate.

The processed cheeses were made in a Stephan UMM-SK5 processing kettle (A. Stephan u. Söhne GmbH \& Co., Hameln, Germany) as described previously (Guinee and O'Kennedy, 2012). All treatment PCP were made on a given day, and triplicate trials were undertaken on 3 separate days over 3 wk. The PCP with target fat levels of 13.8, 18.2, 22.7, 27.9, and 
Table 2. Formulation of processed cheese products with different fat levels ${ }^{1}$

\begin{tabular}{lrrrrr}
\hline & \multicolumn{5}{c}{ Processed cheese product } \\
\cline { 2 - 6 } Item & \multicolumn{1}{c}{ F14 } & F18 & F23 & F28 & F33 \\
\hline Targeted fat level $(\mathrm{g} / 100 \mathrm{~g})$ & 13.8 & 18.2 & 22.7 & 27.9 & 32.5 \\
Ingredient added $(\mathrm{g} / 100 \mathrm{~g})$ & & & & & \\
Cheddar cheese & 0.00 & 0.00 & 12.48 & 58.04 & 43.46 \\
Skim milk cheese & 60.93 & 52.62 & 36.64 & 0.00 & 0.00 \\
Anhydrous butter oil & 13.32 & 17.73 & 18.14 & 8.17 & 17.68 \\
NaCl & 0.21 & 0.21 & 0.21 & 0.21 & 0.21 \\
Disodium orthophosphate & 1.83 & 1.58 & 1.31 & 1.00 & 0.89 \\
Trisodium citrate dihydrate & 0.81 & 0.70 & 0.58 & 0.44 & 0.39 \\
Potassium sorbate & 0.10 & 0.10 & 0.10 & 0.10 & 0.10 \\
Water & 22.81 & 27.08 & 30.53 & 32.04 & 37.50 \\
\hline
\end{tabular}

${ }^{1}$ Three replicate trials, each with 5 levels of treatment (targeted fat level), were undertaken.

$32.5 \mathrm{~g} / 100 \mathrm{~g}$ were designated F14, F18, F23, F28, and F33, respectively. The hot molten mix was poured into a 2 - $\mathrm{kg}$ mold, placed at $4^{\circ} \mathrm{C}$, and held for 2 to $3 \mathrm{~d}$ before analysis.

\section{Compositional Analyses of Cheddar Cheeses}

Cheeses used for processing were analyzed for protein, fat, moisture, and Ca using standard International Dairy Federation methods, and for $\mathrm{pH}$ and $\mathrm{pH} 4.6 \mathrm{SN}$ level (and hence, intact casein level), as described by Guinee and O'Kennedy (2012).

\section{Compositional Analyses of PCP}

The PCP were analyzed in triplicate for contents of protein, fat, moisture, $\mathrm{Ca}$, and $\mathrm{P}$, and $\mathrm{pH}$ and $\mathrm{pH} 4.6 \mathrm{SN}$, as described previously (Guinee and O'Kennedy, 2012).

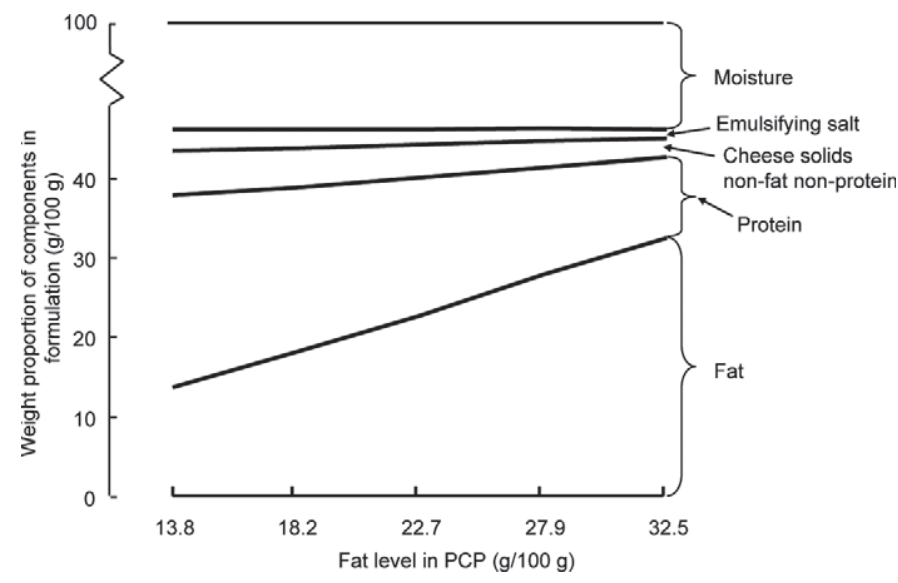

Figure 1. Design of processed cheese product (PCP) formulations with a fixed moisture level, showing linear decrease in protein and emulsifying salt levels with increasing fat level. Cheese solids nonfatnonprotein comprises minerals, mainly calcium and phosphorus, lactate, and peptides. Added $\mathrm{NaCl}$ and potassium sorbate $(\sim 0.31 \mathrm{~g} / 100$ g) are not shown. Formulations are shown in Table 3.
The WSN level was determined by macro-Kjeldahl on a water-soluble extract (WSE) obtained by centrifugation and filtration of a cheese:water homogenate prepared by blending grated processed cheese and water at a weight ratio of $1: 2$, as described previously (Guinee and O'Kennedy, 2012). The levels of pH4.6SN and WSN, as percentages of total $\mathrm{N}$, were used as indices of the degrees of casein hydrolysis (proteolysis) and solubility, respectively, in the PCP.

The levels of water-soluble $\mathrm{Ca}$ and $\mathrm{P}$ in the $\mathrm{PCP}$ were measured on a $12 \%$ TCA filtrate of the WSE. Calcium in the filtrate was determined by atomic absorption (IDF, 2007) and phosphorus by spectrometric determination of molybdenum blue formed on reduction of phosphomolybdic acid by ascorbic acid when sodium molybdate and ascorbic acid are added to the WSE filtrate (IDF, 1990).

\section{Rheology of Unheated PCP}

Refrigerated samples $\left(\sim 8^{\circ} \mathrm{C}\right)$ were compressed to $30 \%$ of original height at a rate of $60 \mathrm{~mm} / \mathrm{min}$ on a TAHDi Texture Profile analyzer (Stable Micro Systems, Godalming, UK), as described previously (Guinee and O'Kennedy, 2012). The following parameters were obtained: fracture stress (defined as the force per unit area to induce fracture) and firmness (the force required to compress the PCP to $30 \%$ of its original height).

\section{Functional Characteristics of the Heated PCP}

Heat-induced flowability was measured as described previously (Guinee and O'Kennedy, 2009): the percentage increase in diameter on heating cheese discs (45 $\mathrm{mm}$ diameter, $6 \mathrm{~mm}$ thick) at $280^{\circ} \mathrm{C}$ for $4 \mathrm{~min}$ according to the principle of the Schreiber test, and as the percentage increase in length of a cheese cylinder $(\sim 15$ g; $22 \mathrm{~mm}$ in diameter, $37.5 \mathrm{~mm}$ long) on heating in an enclosed tube at $180^{\circ} \mathrm{C}$ for $7.5 \mathrm{~min}$ according to the 
Table 3. Composition of processed cheese products $(\mathrm{PCP})$ with different fat levels ${ }^{1}$

\begin{tabular}{|c|c|c|c|c|c|}
\hline \multirow[b]{2}{*}{ Item $^{2}$} & \multicolumn{5}{|c|}{ Processed cheese product } \\
\hline & F14 & F18 & $\mathrm{F} 23$ & F28 & F33 \\
\hline Targeted fat level (g/100 g) & 13.8 & 18.2 & 22.7 & 27.9 & 32.5 \\
\hline Moisture (g/100 g) & $53.7^{\mathrm{a}}$ & $53.4^{\mathrm{a}}$ & $53.2^{\mathrm{a}}$ & $53.8^{\mathrm{a}}$ & $52.7^{\mathrm{a}}$ \\
\hline Fat $(\mathrm{g} / 100 \mathrm{~g})$ & $13.7^{\mathrm{e}}$ & $18.0^{\mathrm{d}}$ & $22.4^{\mathrm{c}}$ & $27.3^{\mathrm{b}}$ & $30.9^{\mathrm{a}}$ \\
\hline Protein (g/100 g) & $25.2^{\mathrm{a}}$ & $21.8^{\mathrm{b}}$ & $17.9^{\mathrm{c}}$ & $13.9^{\mathrm{d}}$ & $11.7^{\mathrm{e}}$ \\
\hline $\mathrm{Ca}(\mathrm{mg} / 100 \mathrm{~g})$ & $766^{\mathrm{a}}$ & $658^{\mathrm{b}}$ & $592^{\mathrm{c}}$ & $463^{\mathrm{d}}$ & $363^{\mathrm{e}}$ \\
\hline $\mathrm{Ca}$ (mg/g of protein) & $30.5^{\mathrm{a}}$ & $30.2^{\mathrm{a}}$ & $33.2^{\mathrm{a}}$ & $33.4^{\mathrm{a}}$ & $30.9^{\mathrm{a}}$ \\
\hline $\mathrm{P}(\mathrm{mg} / 100 \mathrm{~g})$ & $857^{\mathrm{a}}$ & $728^{\mathrm{b}}$ & $666^{\mathrm{b}}$ & $527^{\mathrm{c}}$ & $409^{\mathrm{d}}$ \\
\hline $\mathrm{P}(\mathrm{mg} / \mathrm{g}$ of protein) & $34.1^{\mathrm{a}}$ & $33.3^{\mathrm{a}}$ & $37.2^{\mathrm{a}}$ & $38.0^{\mathrm{a}}$ & $35.1^{\mathrm{a}}$ \\
\hline $\mathrm{pH}$ & $6.2^{\mathrm{a}}$ & $6.2^{\mathrm{a}}$ & $6.1^{\mathrm{a}}$ & $5.9^{\mathrm{b}}$ & $5.8^{\mathrm{b}}$ \\
\hline $\mathrm{pH} 4.6 \mathrm{SN}^{1}(\mathrm{~g} / 100 \mathrm{~g}$ of total $\mathrm{N})$ & $8.5^{\mathrm{ab}}$ & $9.6^{\mathrm{a}}$ & $8.6^{\mathrm{ab}}$ & $7.5^{\mathrm{b}}$ & $7.6^{\mathrm{b}}$ \\
\hline $\mathrm{WSN}^{1}(\mathrm{~g} / 100 \mathrm{~g}$ of total $\mathrm{N})$ & $58.5^{\mathrm{b}}$ & $71.9^{\mathrm{ab}}$ & $71.8^{\mathrm{ab}}$ & $67.2^{\mathrm{ab}}$ & $73.6^{\mathrm{a}}$ \\
\hline $\mathrm{WSP}^{2}(\mathrm{~g} / 100 \mathrm{~g})$ & $14.7^{\mathrm{ab}}$ & $15.7^{\mathrm{a}}$ & $12.9^{\mathrm{b}}$ & $9.2^{\mathrm{c}}$ & $8.5^{\mathrm{c}}$ \\
\hline WSP in moisture phase of PCP ( $\mathrm{g} / 100 \mathrm{~g}$ of moisture) & $27.4^{\mathrm{ab}}$ & $29.4^{\mathrm{a}}$ & $24.1^{\mathrm{b}}$ & $17.1^{\mathrm{c}}$ & $16.3^{\mathrm{c}}$ \\
\hline Water-insoluble protein $^{2}(\mathrm{~g} / 100 \mathrm{~g})$ & $10.4^{\mathrm{a}}$ & $6.1^{\mathrm{b}}$ & $5.0^{\mathrm{bc}}$ & $4.5^{\mathrm{bc}}$ & $3.1^{\mathrm{c}}$ \\
\hline
\end{tabular}

principle of the Olson-Price test. The former is indicative of the melting behavior of PCP when exposed as a toping (e.g., on pizza) during oven heating, and the latter when the PCP is covered, or largely covered, during cooking (e.g., as a cheese slice in hamburger).

Dynamic changes in viscoelastic parameters (elastic modulus, $\left.\mathrm{G}^{\prime}\right)$ and phase angle $(\delta)$ on heating discs $(40$ $\mathrm{mm}$ in diameter, $2 \mathrm{~mm}$ thick) of the PCP from 25 to $80^{\circ} \mathrm{C}$ were measured in a controlled stress rheometer $\left(\mathrm{CSL}^{2} 500\right.$ Carri-Med; TA Instruments Inc., New Castle, DE) by low-amplitude strain oscillation rheometry, as described previously (Guinee and O'Kennedy, 2009). Cheese discs were placed between 2 parallel serrated plates (40 $\mathrm{mm}$ diameter) of the rheometer cell, tempered at $25^{\circ} \mathrm{C}$ for $15 \mathrm{~min}$, and subjected to a harmonic low amplitude shear strain $(\gamma)$ of 0.005 at an angular frequency of $1 \mathrm{~Hz}$. The temperature was then increased to $80^{\circ} \mathrm{C}$ over $15 \mathrm{~min}$.

\section{Statistical Analysis}

The data were analyzed using a randomized complete block design, which incorporated 5 treatment PCP (different fat levels from 13.8 to $32.5 \mathrm{~g} / 100 \mathrm{~g}$ ) and 3 blocks (replicate trials for treatments). Analysis of variance was carried out using a SAS procedure (SAS Institute, 2003), where the effects of treatment and replicate were estimated for all response variables. Duncan's multiple-comparison test was used as a guide for pair comparisons of the treatment means. The data for some response variables were also analyzed by linear regression to establish possible correlations between composition variables (e.g., fat content and firmness).

\section{RESULTS AND DISCUSSION}

\section{Composition of PCP}

The composition of the PCP is given in Table 3. The F23 and F28 PCP had fat levels comparable to those found in retail samples of block PCP on the Irish retail market (22 to $25 \mathrm{~g} / 100 \mathrm{~g}$ ).

Because of the experimental design, reducing the fat content from 30.9 to 13.7 did not affect moisture content but resulted in significant increases in the contents of total protein, water-soluble protein (WSP), waterinsoluble protein (WIP), Ca, and P. The increase in $\mathrm{Ca}$ is consistent with the increases in cheese protein (casein) and associated $\mathrm{Ca}$, and that of $\mathrm{P}$ is consistent with the increases in cheese protein and added DSP in the ES. The pH of the higher-fat PCP (F28, F33) was significantly lower $(\sim 0.25$ units $)$ than that of the other PCP, despite the ratio of ES to protein in the blend being kept constant at 0.105 . This was probably a consequence of the absence of skim milk cheese (which had a higher $\mathrm{pH}$ than the Cheddar cheese; Table 1) in these formulations. Based on previous results on the effect of increasing $\mathrm{pH}$ in the range of 5.2 to 7.0 (Marchesseau et al., 1997; Lee and Klostermeyer, 2001; Guinee, 2009), the lower $\mathrm{pH}$ of the higher-fat PCP (by $\sim 0.3$ units) might be expected to increase their hardness and reduce heat-induced flowability. However, the effect of $\mathrm{pH}$ in the range $5.2-5.9$ on hardness and heat-induced flow has been found to depend on the type of ES used (Lu et al., 2008). For PCP of similar composition, increasing the $\mathrm{pH}$ from 5.3 to 5.6 or 5.9 significantly increased hardness in PCP made with TSC but reduced it in 
PCP made with DSP; for both types of ES, hardness was not influenced by increasing the $\mathrm{pH}$ from 5.6 to 5.9 (Lu et al., 2008). Similarly, the heat-induced flowability was not influenced by increasing $\mathrm{pH}$ from 5.6 to 5.9 in PCP made with DSP but increased significantly in PCP made with TSC. The results of Lu et al. (2008) indicate that differences in the responses of hardness and heat-induced flowability of PCP made with different $\mathrm{ES}$ to $\mathrm{pH}$ might reflect differences in ES type with respect to their acid dissociation constant $\left(\mathrm{p} K_{\mathrm{a}}\right)$ values, ability to complex with $\mathrm{Ca}$, and effect on para-casein solubilization.

\section{Compositions of WSE of PCP}

The compositions of the WSE are presented in Table 4. In agreement with previous studies (Guinee and O'Kennedy, 2009, 2012; Shirashoji et al., 2010), the protein in the PCP was mainly $(\geq 58 \%$ of total) water soluble (nonsedimentable), whereas most of the $\mathrm{Ca}(\geq 75 \%$ of total) and $\mathrm{P}(\geq 66 \%$ of total) was water insoluble (sedimentable); moreover, the calcium-toprotein ratio of the WSP was markedly lower than that of the natural cheese $(\leq 10.5$ vs. $\geq 26.6 \mathrm{mg} / \mathrm{g}$; Tables 1 and 4).

The level of WSN in F14 (58.5\% of total N) was significantly lower than that in F33. Based on the protein content of the PCP and the dilution step during the preparation of the WSE (100 g of PCP per $200 \mathrm{~g}$ of distilled water), the predicted maximum protein content in the WSE (where all the protein in the natural cheese would be solubilized during processing) increased significantly $(P<0.001)$ from 4.6 to $\sim 9.9 \mathrm{~g} / 100 \mathrm{~g}$ as the fat content was reduced over the investigated range (Figure 2). However, actual protein levels (g/100 g) in the WSE were markedly lower than predicted at all fat contents and increased more slowly, with the diver- gence increasing as the fat content was reduced (Figure 2 ). Based on the levels of water and ES added to the formulations (Table 2), the estimated concentration of ES in the water phase surrounding the shredded cheese at the beginning of processing increased from $\sim 3.4$ in F33 to $\sim 11.6 \mathrm{~g} / 100 \mathrm{~g}$ in F14 (Figure 2). The water with dissolved ES that surrounds the cheese shreds at the beginning of processing may be considered an external solvent, and the moisture entrapped within the matrices of the full-fat and skim-cheese shreds as an internal solvent. At the beginning of processing, the difference in concentration of ES between the proposed solvent systems may be considered as a major driving force promoting ES uptake by the internal solvent and concurrent solubilization of the para-casein by added ES. It is expected that the degree of para-casein solubilisation would increase as the magnitude of the ES concentration gradient increased on reducing fat content (Guinee and O'Kennedy, 2012). The increasing divergence between actual and predicted protein concentrations in the WSE suggests a decrease in the efficacy of the ES in sequestering $\mathrm{Ca}$ and promoting para-casein hydration and solubilization as fat content was reduced. The decrease in the extent of protein solubilization may reflect the increasing proportion of skim milk cheese in the formulation as the fat content was reduced; it is envisaged that the high density protein network of the skim milk cheese slows the inward diffusion and penetration of the ES into the shredded cheese during the short processing time. Previous studies have shown that the diffusion rate of solutes (e.g., $\mathrm{NaCl}$, butanoic acid) in cheese moisture is much lower than that in water $(\sim 0.2$ $\mathrm{cm}^{2} / \mathrm{d}$ compared with $\sim 1 \mathrm{~cm}^{2} / \mathrm{d}$ in pure water at $25^{\circ} \mathrm{C}$ for $\mathrm{NaCl}$ ), and is reduced as the protein content of the cheese is increased, because of a greater sieve effect exerted by the para-casein network on the diffusing ions (Guinee and Fox, 2004; Floury et al., 2010). Hence, the

Table 4. Composition of water-soluble cheese extract (WSE) of processed cheese products (PCP) with different fat levels ${ }^{1}$

\begin{tabular}{lccccc}
\hline & \multicolumn{5}{c}{ Processed cheese product } \\
\cline { 2 - 6 } Item & F14 & F18 & F23 & F28 & F33 \\
\hline Targeted fat level (g/100 g) & 13.8 & 18.2 & 22.7 & 27.9 & 32.5 \\
WSE & & & & \\
Protein (g/100 g) & $5.8^{\mathrm{ab}}$ & $6.2^{\mathrm{a}}$ & $5.1^{\mathrm{b}}$ & $3.6^{\mathrm{c}}$ & $3.4^{\mathrm{c}}$ \\
Ca (mg/100 g) & $46.4^{\mathrm{a}}$ & $43.9^{\mathrm{a}}$ & $41.3^{\mathrm{a}}$ & $36.8^{\mathrm{a}}$ & $35.7^{\mathrm{a}}$ \\
Ca (\% of total Ca in PCP) & $15.4^{\mathrm{b}}$ & $17.0^{\mathrm{b}}$ & $18.0^{\mathrm{b}}$ & $20.4^{\mathrm{ab}}$ & $25.0^{\mathrm{a}}$ \\
Ca (mg/g of protein) & $8.0^{\mathrm{ab}}$ & $7.2^{\mathrm{b}}$ & $8.2^{\mathrm{ab}}$ & $9.9^{\mathrm{ab}}$ & $10.5^{\mathrm{a}}$ \\
P (mg/100 g) & $107.6^{\mathrm{a}}$ & $91.2^{\mathrm{a}}$ & $70.3^{\mathrm{b}}$ & $56.5^{\mathrm{b}}$ & $56.0^{\mathrm{b}}$ \\
P (\% of total P in PCP) & $31.8^{\mathrm{a}}$ & $32.0^{\mathrm{a}}$ & $27.1^{\mathrm{a}}$ & $27.8^{\mathrm{a}}$ & $34.3^{\mathrm{a}}$ \\
P (mg/g of protein) & $18.7^{\mathrm{a}}$ & $14.7^{\mathrm{a}}$ & $13.9^{\mathrm{a}}$ & $15.3^{\mathrm{a}}$ & $16.5^{\mathrm{a}}$ \\
Ca/P (mol/mol) & $0.33^{\mathrm{b}}$ & $0.37^{\mathrm{b}}$ & $0.46^{\mathrm{a}}$ & $0.52^{\mathrm{a}}$ & $0.50^{\mathrm{a}}$ \\
\hline
\end{tabular}

${ }^{\mathrm{acc}}$ values within a row not sharing a common superscript differ significantly $(P<0.05)$.

${ }^{1}$ Values presented are the means of 3 replicate samples for each PCP. 


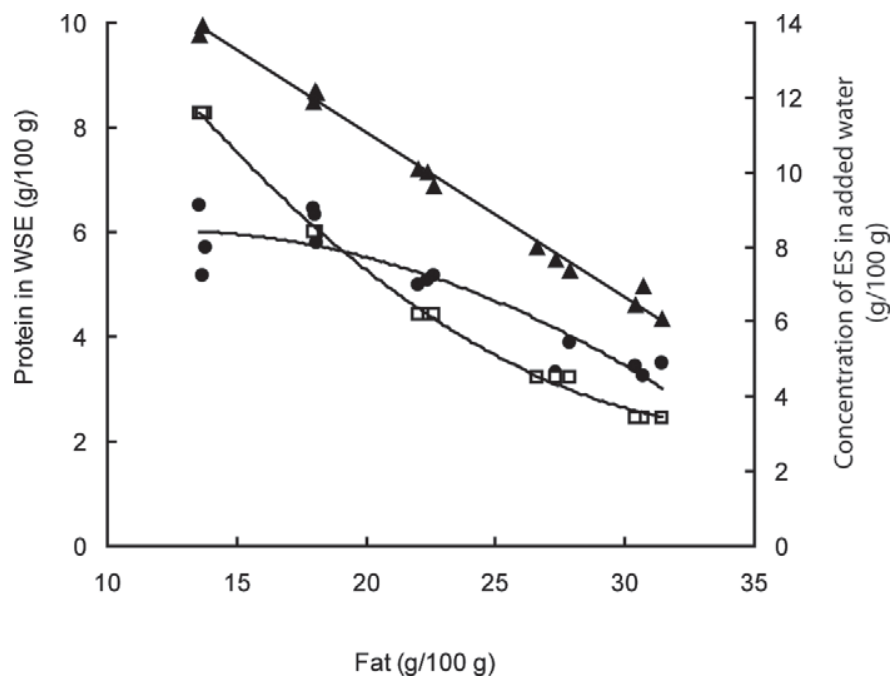

Figure 2. Effect of fat content in processed cheese product (PCP) on the predicted $(\boldsymbol{\Lambda})$ and actual $(\bullet)$ concentrations of protein in the water-soluble extract (WSE) prepared with a PCP:water weight ratio of $1: 2$; predicted levels were calculated based on the protein level of the $\mathrm{PCP}$ and its dilution during preparation of the extract. The concentration of emulsifying salt (ES) in the water added to the PCP during formulation is also shown $(\square)$. The relationship between fat content and predicted protein level in WSE is described by the following equation: Predicted protein level in WSE $=-0.3152$ Fat $+14.212, \mathrm{R}^{2}=0.99$.

inward diffusion of ES (dissolved in the added water) into the moisture phase of the skim cheese during processing would be greatly impeded because of its higher protein concentration compared with the full-fat cheese (Guinee and O'Kennedy, 2012). Consequently, the relatively short time during the manufacture of PCP (typically $5 \mathrm{~min}$ ) may not allow sufficient time for optimized ion-exchange interaction between the para-casein and the ES, and hence for protein solubilization, in the case of skim milk cheese.

Although the mean values of calcium in the WSE were not influenced by fat content of the PCP, regression analysis showed a significant trend of increasing $\mathrm{Ca}$ in WSE with reducing fat content $(P<0.01)$. In contrast, when expressed as a percentage of total $\mathrm{Ca}$ in the PCP, the Ca in WSE decreased significantly as the fat content was reduced (Table 4). The concentration of $\mathrm{P}$ in the WSE increased significantly as the fat content was reduced, a trend consistent with the higher levels of added DSP (Table 2). However, when expressed as a percentage of total $\mathrm{P}$ in the $\mathrm{PCP}$, it was not affected by fat level. Hence, the molar ratio of Ca to $\mathrm{P}$ in the WSE decreased significantly as the fat content was reduced. The lower Ca-to-P ratio further corroborates the premise that, within the time frame of typical processing, the use of high levels of skim cheese (e.g., in the F14 $\mathrm{PCP}$ ) results in lower levels of calcium chelation by the sodium phosphate ES (Table 2).

\section{Rheological Properties of Uncooked PCP}

The functional properties of the PCP are shown in Table 5. Reducing the fat content significantly affected firmness, which increased exponentially as the fat content was reduced (Figure 3). The increase in firmness as fat level was reduced is consistent with trends noted in previous studies (Templeton and Sommer, 1932; Drake et al., 1999). Similarly, Solowiej (2012) reported that the hardness of cheese analogs, formed by blending acid casein dispersions and $\mathrm{AMF}$, increased as the protein content of the casein dispersion was increased from 12 to $20 \mathrm{~g} / 100 \mathrm{~g}$ and the level of AMF inclusion was reduced from 30 to $10 \mathrm{~g} / 100 \mathrm{~g}$, despite an estimated increase in moisture content from $\sim 62$ to $74 \mathrm{~g} / 100 \mathrm{~g}$. The trend is also consistent with the inverse relationship between fat content and firmness reported for natural cheeses (Tunick et al., 1993; Fenelon and Guinee, 2000; Gwartney et al., 2002).

The protein in PCP may be considered to exist in varying degrees of aggregation. During processing, the calcium phosphate para-casein network of the natural cheese is more, or less, disintegrated by the action of the ES, with the insoluble calcium phosphate casein being partially transformed into WSP derivatives (with lower levels of bound $\mathrm{Ca}$ and $\mathrm{P}$, Table 3 ). The WIP may be considered as closely resembling the concentrated gelled calcium phosphate para-casein in the natural cheese. In the current study, the levels of both WSP and WIP increased significantly as the fat content was reduced, with the content of former being higher than that of the latter at all fat levels (Table 3, Figure 4).

The question arises of how WSP, generated by disintegrating the protein network of natural cheeses, contributes to structure and firmness in PCP. The contribution of the WSP may be considered by extrapolation to the results from model studies on the rheology of concentrated casein dispersions. Ultracentrifugation of milk (e.g., at $100,000 \times g$ for $60 \mathrm{~min}$ at $\sim 20^{\circ} \mathrm{C}$ ) results in concentration of casein micelles in the form of a pellet with $\sim 20 \%$ protein and $80 \%$ moisture, and which at 5 to $10^{\circ} \mathrm{C}$ behaves as a viscoelastic solid (Horne, 1998), the elasticity $\left(\mathrm{G}^{\prime}\right)$ of which is independent of shear rate. This behavior illustrates the tendency of casein dispersions to form polymeric structures when concentrated. The experiments of Bouchoux et al. (2009), involving the concentration of casein micelle dispersions in milk ultrafiltrate by equilibrium dialysis against solvents of different osmotic pressure, are also of interest. Increasing the protein concentration of dispersions progressively to $>20$ to $25(\mathrm{~g} / 100 \mathrm{~g})$ resulted in their transformation from opaque liquids to translucent coherent solids as the micelles became increasingly dehydrated and concentrated and interacted irreversibly to form a 


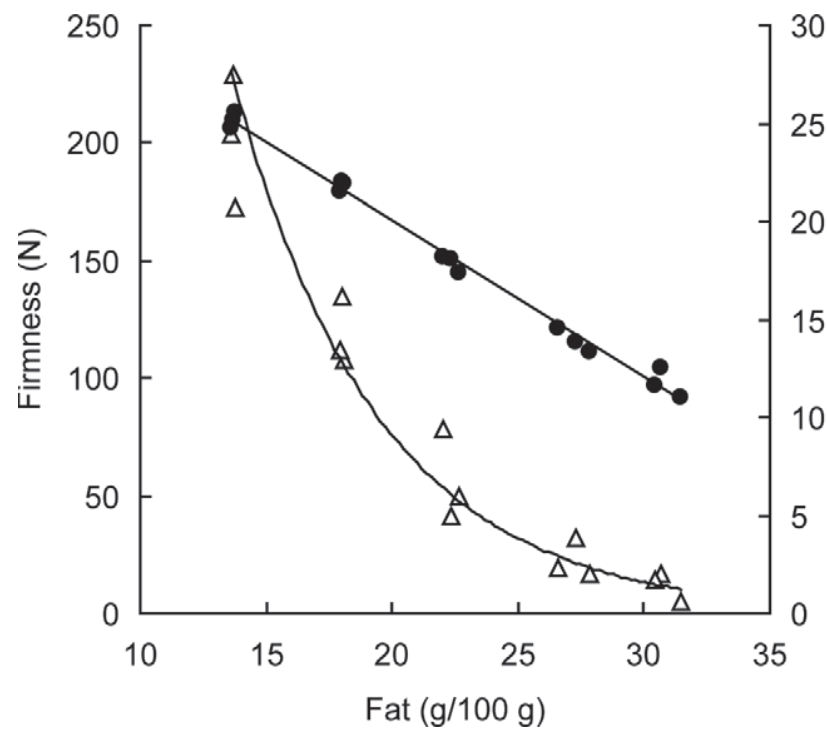

Figure 3. Effect of fat content on firmness $(\Delta)$ and protein content $(\bullet)$ in processed cheese product. The dependencies of protein and firmness on fat content are described by the following respective equations: Protein $=-0.8009$ Fat $+36.062, \mathrm{R}^{2}=0.99$; Firmness $=$ $2,448 \mathrm{e}^{-0.1738 \text { Fat }}, \mathrm{R}^{2}=0.94$.

structural continuum. The calculated concentration of WSP in the moisture phase of the PCP (based on N solubility values in the WSE and the dilution in preparing the WSE) increased from $\sim 16 \mathrm{~g} / 100 \mathrm{~g}$ in the F28 to 27 to $29 \mathrm{~g} / 100 \mathrm{~g}$ in F14 and F18 (Table 3). Hence, based on extrapolation from model studies (Horne, 1998; Bouchoux et al., 2009), it is hypothesized that the WSP contributes to immobilization and structuring of the moisture phase of the PCP, especially in the lower-fat PCP (F14, F18, and F23) where the levels of protein in the moisture phase are greater than $20 \mathrm{~g} / 100$ g. It also noteworthy that the calcium-to-casein ratio of the WSE ( 8 to $10.5 \mathrm{mg} / \mathrm{g}$, Table 4 ) indicates that a significant portion $(25-30 \%)$ of the original calcium

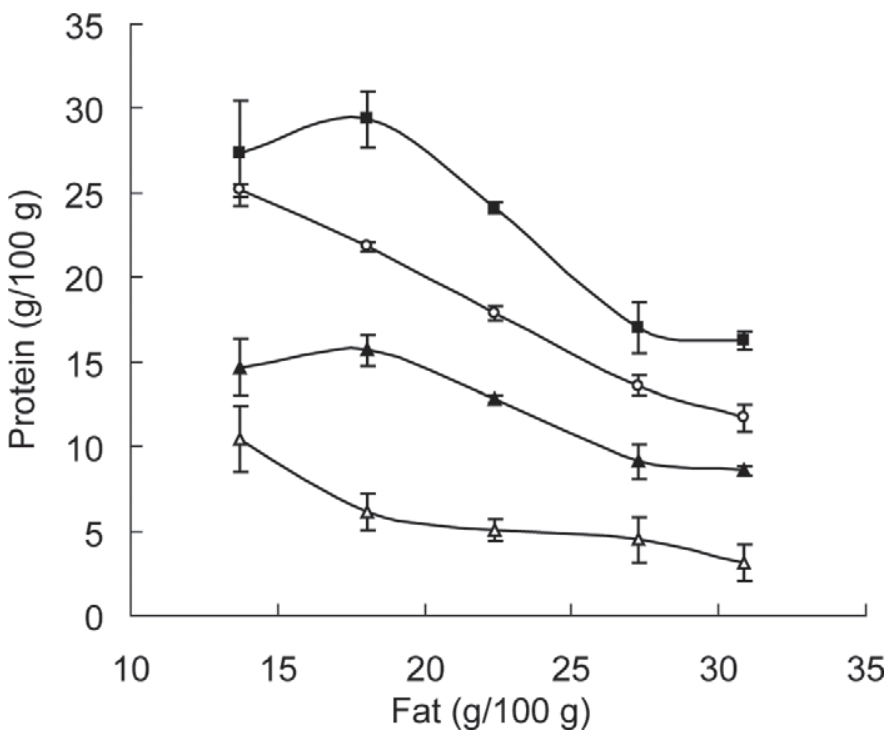

Figure 4. Effect of fat content on the concentration of total protein $(\bigcirc)$, water-insoluble protein $(\Delta)$, water-soluble protein $(\mathbf{\Lambda})$, and watersoluble protein in the moisture phase $(\mathbf{\square})$ of processed cheese product.

$(\sim 31 \mathrm{mg} / \mathrm{g})$ remains with the WSP and is likely to contribute to some degree of intermolecular bridging, and hence structuring, of the WSP in the aqueous phase. This hypothesis is supported by previous studies on PCP (Shirashoji et al., 2006; Guinee and O'Kennedy, 2012), which found that reducing the water-to-PCP ratio during the preparation of WSE significantly reduced the weight:volume of the resultant WSE, and that no WSE was obtained below a critical ratio (e.g., 65:35 in PCP made with $3.4 \mathrm{~g} / 100 \mathrm{~g}$ disodium orthophosphate; Guinee and O'Kennedy, 2012). The studies attributed the latter effect to the high level of WSP in the moisture of the WSE, which increased its viscosity, through immobilization of the water phase, thereby making it nonextractable. It would be of interest to validate this

Table 5. Rheological and cooking properties of processed cheese products (PCP) with different levels ${ }^{1}$

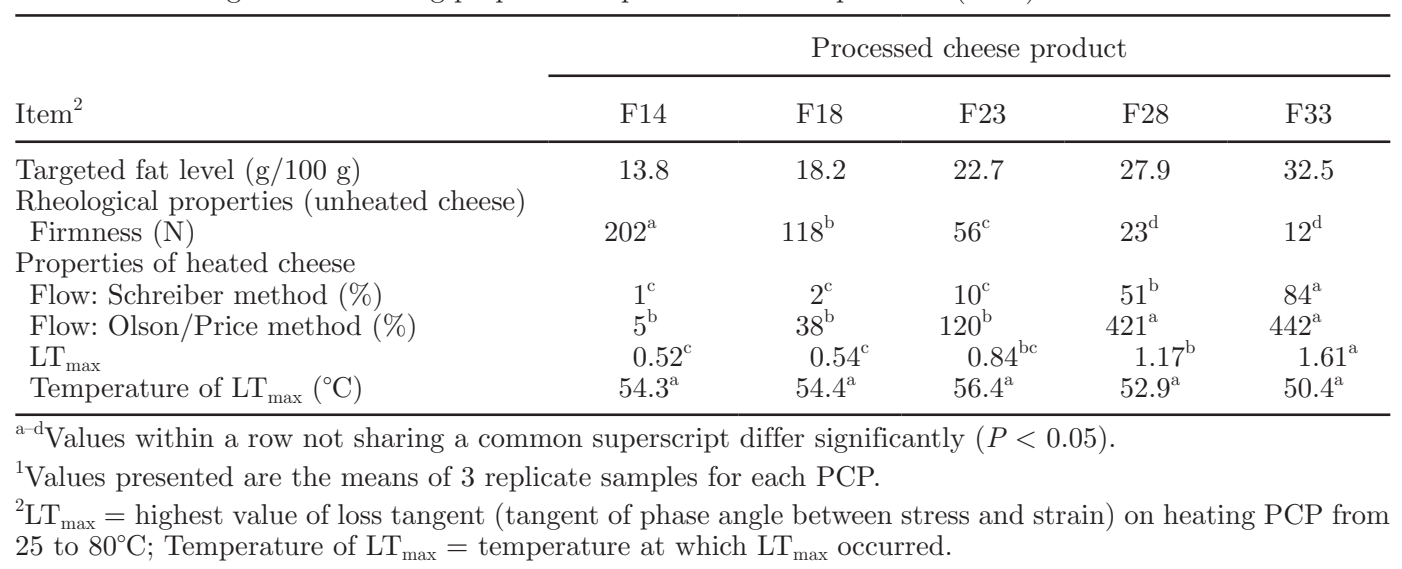


hypothesis in future studies by investigating the rheological and microstructural properties on model dispersions of hydrated rennet casein under various conditions, such as varying protein concentration, solvent quality (types and levels of ES, $\mathrm{pH}$ ), and temperature. Alternatively, such studies could be performed using the WSP purified from the WSE of PCP.

Other studies of relevance here are those showing the potential aggregation and gelation of milk or dilute milk protein dispersions (2 to $10 \mathrm{~g} / 100 \mathrm{~g}$ ) by added phosphates including DSP (Gaucher et al., 2007; Mizuno and Lucey, 2007). This gelation phenomenon was generally enhanced by increasing concentrations of casein, $\mathrm{Ca}^{2+}$, and DSP (to $\geq 50 \mathrm{mM}$ ). Based on the $\mathrm{P}$ concentrations in the WSE (Table 4), the estimated concentrations of soluble P, expressed as DSP $\left(\mathrm{Na}_{2} \mathrm{HPO}_{4}\right)$, in the moisture phase of the (undiluted) PCP increased from 46 to $\sim 89 \mathrm{mM}$ as the fat content was reduced. Hence, the propensity to a potential phosphate-induced gelation of soluble protein in the moisture phase of the PCP is likely to increase as fat content is reduced because of the increases in concentrations of protein, $\mathrm{Ca}^{2+}$, and phosphate.

\section{Flowability and Rheology of Heated PCP}

The flowability of the heated cheese at $280^{\circ} \mathrm{C}$ and $170^{\circ} \mathrm{C}$, as measured using the Schreiber- and OlsonPrice-based methods, respectively, decreased significantly with reduced fat level, with very little flow being observed at a fat content $\leq 18 \mathrm{~g} / 100 \mathrm{~g}$ (Table 5). Regression analysis indicated that flowability increased exponentially with fat content (Figure 5).

Likewise, reducing fat content significantly reduced the magnitude of the highest value of loss tangent (tangent of phase angle between stress and strain) on heating PCP from 25 to $80^{\circ} \mathrm{C}\left(\mathbf{L T}_{\max }\right.$; Table 5), with $\mathrm{F} 14$ and F18 undergoing little or no change on heating and displaying a high ratio of elastic-to-viscous character (loss tangent $\ll 1.0$ ) over the entire temperature range investigated (25 to $80^{\circ} \mathrm{C}$; Figure 6 ). Regression analysis indicated an exponential increase in $\mathrm{LT}_{\max }$ with fat content (Figure 5). Similarly, reducing the fat content of natural cheese has been found to significantly reduce $\mathrm{LT}_{\max }$, despite the concomitant increase in moisture level (Ustunol et al., 1995; Guinee et al., 2000).

The deterioration in flowability and $\mathrm{LT}_{\max }$ of $\mathrm{PCP}$ on reducing fat content is expected because of the increase in the volume fraction of the protein network and reduction in fat content per se. Microscopy studies on PCP show that the protein exists as aggregates, knitted into strands and potential networks with different degrees of continuity, depending on processing conditions (shear, time; Heertje et al., 1981; Heertje, 1993). Based on the
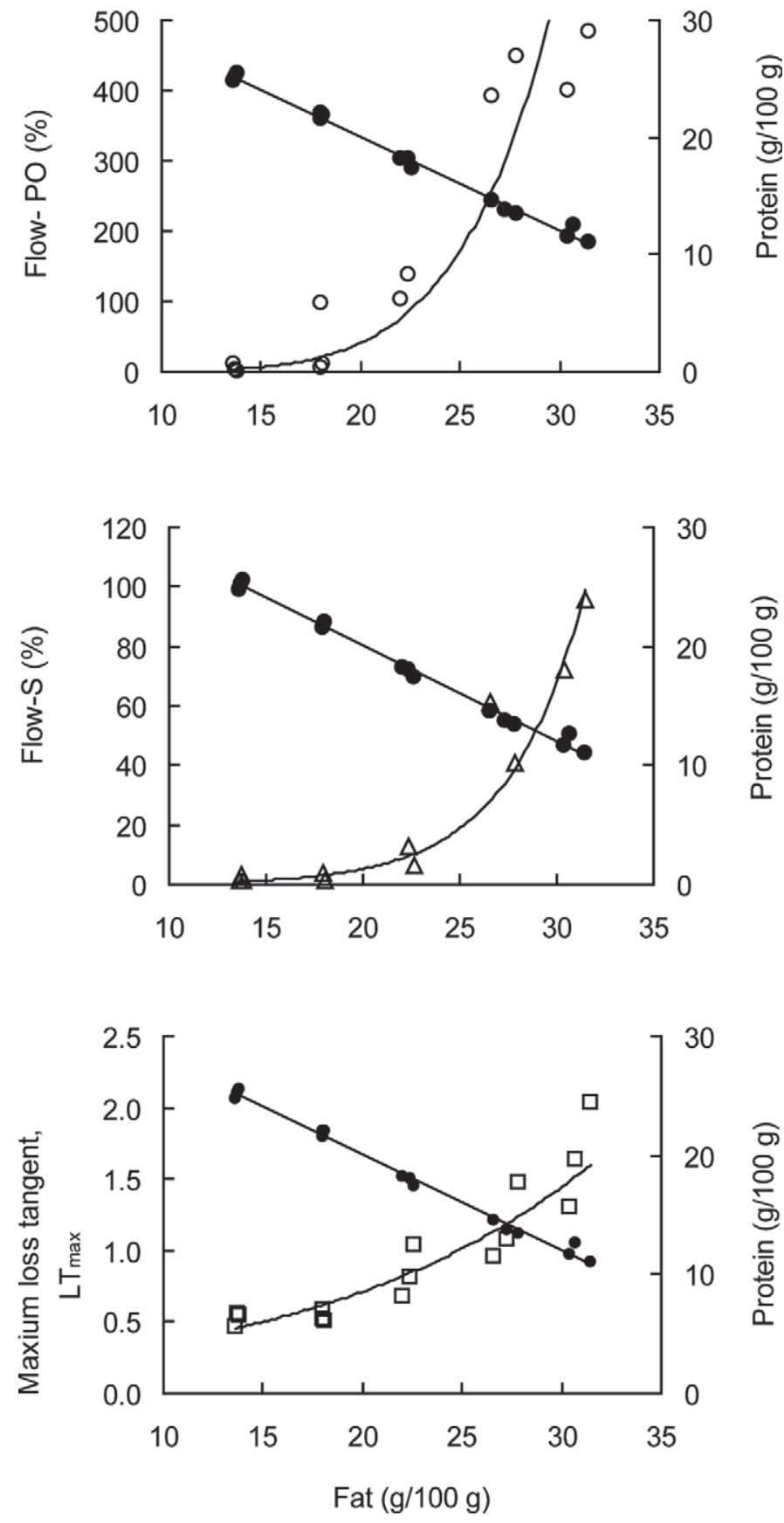

Figure 5. Effect of fat content on the heat-induced flowability, as measured using modified Price-Olson $(\mathrm{O}$; Flow-PO) and Schreiber $(\Delta ;$ Flow-S $)$ methods, maximum loss tangent $\left(\mathrm{LT}_{\max }\right)$ on heating from 25 to $80^{\circ} \mathrm{C}(\square)$, and concentration of protein $(\bullet)$ in processed cheese product. The relationships between fat content and Flow-PO, Flow-S, and $\mathrm{LT}_{\max }$ are as follows: Flow-PO $=2 \times 10^{-7} \mathrm{Fat}^{6.462}, \mathrm{R}^{2}=0.83$; Flow-S $=0.0302 \times \mathrm{e}^{0.257 \mathrm{Fat}}, \mathrm{R}^{2}=0.87 ; \mathrm{LT}_{\max }=0.174 \times \mathrm{e}^{0.071 \mathrm{Fat}}, \mathrm{R}^{2}$ $=0.88$.

shrinkage and swelling behavior of concentrated casein dispersions (Horne, 1998) and natural cheese (Dave et al., 2001; Pastorino et al., 2002) during heating and cooling, it is postulated that the protein structures as- 


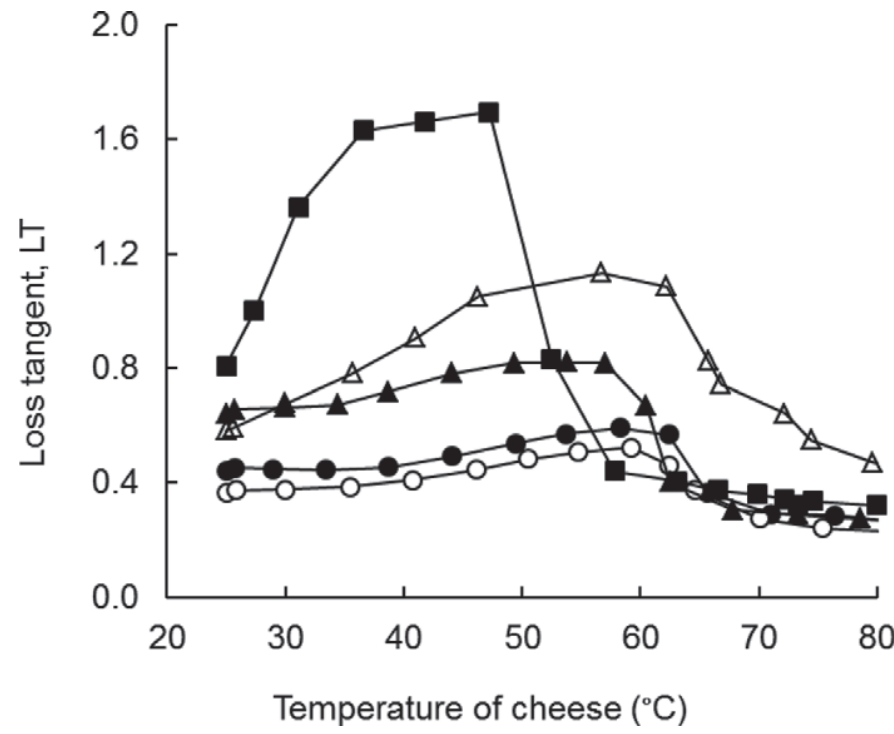

Figure 6. Loss tangent of processed cheese product, with different

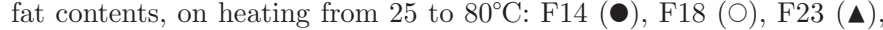
F28 $(\triangle)$ and F33 $(\mathbf{\square})$. The fat contents are given in Table 1.

sociated with the soluble and insoluble protein in PCP similarly shrink on heating, resulting in the expression of moisture, which in turn confers greater mobility and fluidity to the melting PCP mass. Similarly, reducing the fat content favors a reduction in level of free oil released on cooking and its lubricating effect on the surfaces of protein structural entities during heat-induced displacement (Kindstedt and McConnell, 1990). Furthermore, the increase in protein-to-fat ratio of the PCP as fat content is reduced is conducive to a higher degree of fat emulsification and its concomitants, lower heat-induced oiling-off, flow, and fluidity (Rayan et al., 1980; Shimp, 1985; Neville, 1998).

Based on our results, improvement of the properties of reduced-fat PCP may be approached by diluting the protein phase (e.g., by increasing the moisture content of the PCP) or attenuating the potential structure-forming ability of the protein fraction by using natural cheese with lower intact casein content and lower calcium-to-casein ratio or reducing the ratio of phosphate-based ES to protein during formulation of the PCP (Shirashoji et al., 2010). Interestingly, lowering the level of added DSP from 3.4 to $0.75 \mathrm{~g} / 100 \mathrm{~g}$ has been found to reduce firmness and increase loss tangent and flowability of processed cheeses with fixed levels of total protein $(19 \mathrm{~g} / 100 \mathrm{~g})$ and moisture $(48 \mathrm{~g} / 100 \mathrm{~g})$ (Guinee and O'Kennedy, 2012).

\section{CONCLUSIONS}

Reducing the fat content of PCP resulted in a curvilinear increase in firmness and curvilinear decreases in flowability and loss tangent on heating. These changes coincided with significant increases in the levels of total protein, WSP, and WIP. It is hypothesized that the WSP is aggregated to varying degrees and confers a degree of structure and viscosity or rigidity to the moisture phase of the $\mathrm{PCP}$, and that aggregation of the WSP is enhanced by increasing the concentrations of protein, $\mathrm{Ca}$, and $\mathrm{P}$. Further, it is proposed that the WSP protein structures in the moisture phase occur to a higher degree as the fat content of the PCP is reduced, and contribute (along with the increasing WIP) to the increase in firmness and flow-resistance on cooking. Another interesting finding of the current study was that the protein content of the WSE increased to a lesser degree than predicted (based on the total protein level), with the divergence between actual and predicted protein concentrations becoming more pronounced as the fat level decreased. We hypothesize that the latter occurrences reflect a decreasing interaction of the ES with the cheese protein because of its poor penetration of the high density matrix of skim cheese, the proportion of which increased in the formulation as the fat content was reduced. Based on this hypothesis, the use of high levels of reduced-fat, hard, rennet curd cheese during processing (e.g., in manufacture of reduced-fat processed cheeses) may necessitate altered protocols to allow more effective penetration of the ES into, and interaction with, the cheese matrix (e.g., finer grinding of the cheese before processing, increasing the ratio of ES to protein, preblending of formulation ingredients at room temperature before processing, or extending the processing time).

\section{ACKNOWLEDGMENTS}

The authors gratefully acknowledge the technical assistance of E. O. Mulholland and C. Mullins (Teagasc Food Research Centre Moorepak, Fermoy, Co. Cork, Ireland) and the financial assistance of the Dairy Research Trust Co-Operative Society Limited (Dublin, Ireland).

\section{REFERENCES}

Bouchoux, A., P. E. Cayemitte, J. Jardin, G. Gésan-Guiziou, and B. Cabane. 2009. Casein micelle dispersions under osmotic stress. Biophys. J. 96:693-706.

Brickley, C. A., M. A. E. Auty, P. Piraino, and P. L. H. McSweeney. 2007. The effect of natural Cheddar cheese ripening on the functional and textural properties of the processed cheese manufactured therefrom. J. Food Sci. 72:C483-C490.

Brickley, C. A., S. Govindasamy-Lucey, J. J. Jaeggi, M. E. Johnson, P. L. H. McSweeney, and J. A. Lucey. 2008. Influence of emulsifying salts on the textural properties of non-fat process cheese made from direct acid cheese bases. J. Dairy Sci. 91:39-48.

Brummel, S. E., and K. Lee. 1990. Soluble hydrocolloids for fat replacement in processed cheese spreads. J. Food Sci. 55:1290-1292, 1307. 
Campbell, T. C., B. Parpia, and J. Chen. 1998. Diet, lifestyle, and the aetiology of coronary artery disease: The Cornell China study. Am. J. Cardiol. 82(Suppl. 2):18T-21T.

Carrera-Bastos, P., M. Fontes-Villalba, J. H. O'Keefe, S. Lindeberg, and L. Cordain. 2011. The western diet and lifestyle and diseases of civilization. Res. Rep. Clin. Cardiol 2:15-35.

Dave, R. I., D. J. McMahon, and J. R. Broadbent. 2001. Reversibility of the temperature-dependent opacity of non-fat Mozzarella cheese. J. Dairy Sci. 84:2364-2371.

Drake, M. A., V. D. Truong, and C. R. Daubert. 1999. Rheological and sensory properties of reduced-fat processed cheeses containing lecithin. J. Food Sci. 64:744-777.

Fenelon, M. A., and T. P. Guinee. 2000. Primary proteolysis and textural changes during ripening in Cheddar cheeses manufactured to different fat contents. Int. Dairy J. 10:151-158.

Floury, J., S. Jeanson, S. Aly, and S. Lortal. 2010. Determination of the diffusion coefficients of small solutes in cheese: A review. J. Dairy Sci. Technol. 90:477-508.

Garimella Purna, S. K., A. Pollard, and L. E. Metzger. 2006. Effect of functionality and manufacturing parameters on process cheese food functionality. 1. Trisodium citrate. J. Dairy Sci. 89:2386-2396.

Gaucher, I., M. Piot, E. Beaucher, and F. Gaucheron. 2007. Physico-chemical characterization of phosphate-added skim milk. Int. Dairy J. 17:1375-1383.

Guinee, T. P. 2009. The role of dairy ingredients in processed cheese products. Pages 507-538 in Dairy-Derived Ingredients. M. Corredig, ed. Woodhead Publishing, Oxford, UK.

Guinee, T. P., M. A. E. Auty, M. O. Corcoran, and E. O. Mulholland. 2000. Preliminary observations on effects of fat content and degree of fat emulsification on the structure-functional relationship of Cheddar-type cheese. J. Texture Stud. 31:645-663.

Guinee, T. P., and P. F. Fox. 2004. Salt in cheese: Physical, chemical and biological aspects. Pages 205-259 in Cheese Chemistry, Physics and Microbiology. 3rd ed. P. F. Fox, P. L. H McSweeney, T. M. Cogan, and T. P. Guinee, ed. Elsevier Academic Press, London, UK.

Guinee, T. P., and B. T. O'Kennedy. 2009. The effect of calcium content of Cheddar-style cheese on the biochemical and rheological properties of processed cheese. J. Dairy Sci. Technol 89:317-333.

Guinee, T. P., and B. T. O'Kennedy. 2012. Reducing the level of added disodium phosphate alters the chemical and physical properties of processed cheese. J. Dairy Sci. Technol 92:469-486.

Gwartney, E. A., E. A. Foegeding, and D. K. Larick. 2002. The texture of commercial full-fat and reduced-fat cheese. J. Food Sci. $67: 812-816$.

Hassan, A. N., S. Awad, and V. V. Mistry. 2007. Reduced fat process cheese made from young reduced fat cheddar cheese manufactured with exopolysaccharide-producing cultures. J. Dairy Sci. 90:3604-3612.

Heertje, I. 1993. Structure and function of food products: A review. Food Struct. 12:343-364.

Heertje, I., M. J. Boskamp, F. van Kleef, and F. H. Gortemaker. 1981. The microstructure of processed cheese. Neth. Milk Dairy J. $35: 177-179$.

Horne, D. S. 1998. Casein interactions: Casting light on the black boxes, the structure in dairy products. Int. Dairy J. 8:171-177.

IDF (International Dairy Federation). 1990. Milk: Determination of total phosphorus content by the spectrometric method. 42B. IDF, Brussels, Belgium.

IDF (International Dairy Federation). 2007. Milk and milk products. Determination of calcium, magnesium, sodium, potassium and magnesium contents. Atomic absorption spectrometric method. International Standard ISO 8070 and IDF Standard 119. IDF, Brussels, Belgium.

Kindstedt, P. S., and S. L. McConnell. 1990. Measurement of viscoelastic consistency and emulsion stability of melted processed cheeses by helical viscometry and centrifugal free oil separation. J. Dairy Sci. 73(Suppl.1):119. (Abstr.)

Lee, S. K., and H. Klostermeyer. 2001. The effect of $\mathrm{pH}$ on the rheological properties of reduced-fat model processed cheese spreads. Lebenson. Wiss. Technol. 34:288-292.

Lee, W., S. Clark, and B. G. Swanson. 2006. Low fat process cheese food containing ultra-high pressure-treated whey protein. J. Food Process. Preserv. 30:164-179.

Lu, Y., N. Shirashoji, and J. A. Lucey. 2008. Effects of pH on the textural properties and meltability of pasteurized process cheese made with different types of emulsifying salts. J. Food Sci. 73:E363E369.

Marchesseau, S., E. Gastaldi, A. Lagaude, and J.-L. Cuq. 1997. Influence of $\mathrm{pH}$ on protein interactions and microstructure of processed cheese. J. Dairy Sci. 80:1483-1489.

Mizuno, R., and J. A. Lucey. 2007. Properties of milk protein gels formed by phosphates. J. Dairy Sci. 90:4524-4531.

Muir, D. D., S. A. R. Williams, A. Y. Tamime, and M. E. Shenana. 1997. Comparison of sensory profiles of regular and reduced-fat commercial processed cheese spreads. Int. J. Food Sci. Technol. $32: 279-287$.

Neville, D. P. 1998. Studies on the melting properties of cheese analogues. MS Thesis. National University of Ireland, Cork.

Pastorino, A. J., R. I. Dave, C. J. Oberg, and D. J. McMahon. 2002. Temperature effect on structure-opacity relationships of nonfat Mozzarella cheese. J. Dairy Sci. 85:2106-2113.

Raval, D. M., and V. V. Mistry. 1999. Application of ultrafiltered sweet buttermilk in the manufacture of reduced-fat process cheese. J. Dairy Sci. 82:2334-2343.

Rayan, A. A., M. Kaláb, and C. A. Ernstrom. 1980. Microstructure and rheology of process cheese. Scan. Electron Microsc. 3:635643.

SAS Institute. 2003. SAS User's Guide: Statistics. Version 9.1.3. SAS Institute Inc., Cary, NC.

Shenana, M. E., G. F. El-Nagar, S. El-Shibiny, and S. M. Abdou. 2007. Effect of fat content, fat replacers and emulsifying salts on half and low-fat processed cheese spreads. J. Saudi Soc. Food Nutr. 2:53-69.

Shimp, L. A. 1985. Process cheese principles. Food Technol. 39:63-64, $66,68,70$.

Shirashoji, N., J. J. Jaeggi, and J. A. Lucey. 2006. Effect of trisodium citrate concentration and cooking time on the physicochemical properties of pasteurized process cheese. J. Dairy Sci. 89:15-28.

Shirashoji, N., J. J. Jaeggi, and J. A. Lucey. 2010. Effect of sodium hexametaphosphate concentration and cooking time on the physicochemical properties of pasteurized process cheese. J. Dairy Sci. 93:2827-2837.

Simopoulos, A. P. 2002. The importance of the ratio of omega-6/omega-3 essential fatty acids. Biomed. Pharmacother. 56:365-379.

Solowiej, B. 2012. Textural, rheological and melting properties of acid reduced-fat processed and cheese analogues. Milchwissenschaft 67:9-13.

Swenson, B. J., W. L. Wendorff, and R. C. Lindsay. 2000. Effects of ingredients on the functionality of fat-free process cheese spreads. J. Food Sci. 65:822-825.

Templeton, H. L., and H. H. Sommer. 1932. Factors affecting the body and texture of processed cheese. J. Dairy Sci. 15:29-41.

Tunick, M. H., E. L. Malin, P. W. Smith, J. J. Shieh, B. C. Sullivan, K. L. Mackey, and V. H. Holsinger. 1993. Proteolysis and rheology of low-fat and full-fat Mozzarella cheeses prepared from homogenized milk. J. Dairy Sci. 76:3621-3628.

Ustunol, Z., K. Kawachi, and J. Steffe. 1995. Rheological properties of Cheddar cheese as influenced by fat reduction and ripening time. J. Food Sci. 60:1208-1210. 